\title{
Traditional Fairy Tales and Shrek
}

\author{
Vicky Tchaparian
}

Lebanese University

\begin{abstract}
Although Brothers Grimm collection of fairy tales have somehow the same cliché of plot, setting, and characters, in the fairy tale of Shrek the protagonist doesn't follow this cliché. Shrek the protagonist is not a classical fairy tale of the handsome prince in quest of a beautiful princess; instead, he is an ogre. Grimm brothers wrote on text that they collected from the words of mouth giving the traditional tales a special structure and characters. However, compared to Grimm Brothers' tales, Shrek the film, has a completely different structure and characters.

In this paper I try to disclose the fact that Grimm folk tales which reveal the mentality of the $19^{\text {th }}$ century as well as that of the earlier ages that belong to specific cultures (especially to the European culture and their mentality) are completely different than that of Shrek the film.
\end{abstract}

Key words: Shrek, Brothers Grimm, traditional, protagonist, folk tales, animation.

\section{Introduction}

Traditionally, fairy tales were told orally and handed down from one generation to another by the word of mouth until the $19^{\text {th }}$ century when they developed into written texts. Later, they presented them with special effects in the film genre. The first collectors of fairy tales in an attempt to preserve them were Jacob and Wilhelm Grimm known under the name of Brothers Grimm. Their first edition of folk tales which appeared in 1812 remains a treasure for folklorists. Wystan Hugh Auden, the Anglo-American poet and critic, claimed that Grimms' fairy tales "rank next to the Bible in 
importance" (Auden 2015:240). However, the extremely important collection of fairy tales has the same cliché of plot, setting, and characters, which the fairy tale of Shrek doesn't follow.

As for the plot of Brothers Grimm collection of Folk tales, they are culture specific because they tell a story true for a certain society and a certain time in the past. In her journal called Tale Spinners: Submerged Voices in Grimm's Fairy Tales Ruth B. Bottigheimer says, "the folktales which appeared during the Grimms' lifetime in seven large and twelve small editions from 1812 to 1856 - can be seen as a sourcebook for the mentality not only of the 19th century but also of former ages." (Bottingheim 1982:141). Thus, Brothers Grimm fairy tale collection reveals the mentality of the $19^{\text {th }}$ century when Brothers Grimm lived, as well as the mentality of the older ages when these fairy tales were created.

It is worth mentioning that in Grimms' time and earlier, these tales were read only to/by European children to teach them moral lessons. However, in the current time, they are read by various people that belong to different social and ethnic groups. For this specific reason, the plot and setting of Shrek (the film) is much more different than those told by Brothers Grimm.

\section{A Comparative Study of the Traditional Fairy Tales and Shrek}

In their book Gender and Society, Lori Baker-Sperry and Liz Grauerholz mention: "These folk and fairy tales were originally used as primers for relatively affluent European children and served to impart moral lessons to them (Zipes 1988). Today, these tales, at least those that survived into the twentieth century, are read by children all across the globe, they belong to various social class racial and ethnic groups" (Zipes 1997; Baker-Sperry and Grauerholz 2003:714).

Furthermore, these fairy tale stories were affected by the political and social changes that happened in various parts of the world. An obvious example is the absence of African children of color from the pages of these books. Research by Pescosolido, Grauerholz, and Milkie (1997) found that "during periods of intense racial conflict and significant political gains by 
African Americans, Black characters virtually disappeared from children's books" (Baker-Sperry and Grauerholz 2003:14). Thus, because of the racial conflicts, black children or characters disappeared from children's books although there might be many black children reading stories from those books. In the Journal of Negro Education, Dorothy L. Hurley notes: "Tatum (1997) suggests that identity formation in children of color in the United States travels a different path from that of children who belong to the dominant culture" (Hurley 2005:221). Thus, these stories play a major role in forming the identities of these children undervaluing the black identity and overvaluing the white one in a certain period of their childhood.

As for the age of the people who read these fairy tales, it has varied since the earlier ages. In The Journal of American Folklore, Kristin Wardetzky writes: "As early as 1923, Charlotte Biihler's Viennese study confirmed the fact that fairy tales were the favorite reading material for eight- to nineyear-olds (Federspiel 1968:124), and almost sixty years later Werner Psaar and Manfred Klein ascertained that "there can be no question of a disappearance of interest in fairy tales either among children or among adults" (Psaar and Klein 1980:159; Wardetzky 1990:157).

Thus, these fairy tales that play an important part in forming the identity of children can be read by either children or adults. However, passing by the word of mouth to the written words on papers, they didn't remain there. They traveled far to Hollywood studios to be presented more powerfully with the use of special effects and animation to be watched by different children as well as adults in different parts of the world.

Something which is obviously clear is that most of these fairy tales have the same plot and structure. The beginning of the fairy tale films, like that of the text starts with the words "once upon a time" and ends with "happily ever after." The hero and the heroine may suffer a lot, be enchanted by an evil magician, be of different social classes (usually extremely rich or miserably poor), yet they will eventually meet somewhere and somehow, where the magic will lose its power by a fairy godmother. Most of the heroines will wait for the charming prince to come and save them. These 
heroines are magnificently beautiful princesses and their heroes are extraordinarily charming princes who live in faraway castles and places of unimaginable beauty where the flowers never fade and rivers never stop flowing.

According to many critics, most fairy tales have the same plot and structure, yet, the plots of these fairy tales are culture specific, and they reveal the beliefs of a given society. In her journal Fairy Tales, Folk Narrative Research and History Ruth B. Bottigheimer claims: "Folk narrative specialists demonstrate a growing - and correspondding - conviction that folk and fairy tales are historically determined, a belief that content, style and plot grow out of the surroundding culture rather than representing an ageless and unchanging tradition" (Bottingheim 1982:343).

However, in Shrek the protagonist follows neither style nor plot or characters of the traditional fairy tale since both heroes are ogres instead of being a prince charming and an enchanting the princess. They both live in a swamp instead of a castle and they both are chubby and ugly. Thus, it can be said that Shrek follows the anti-racist educational approach that seeks to challenge inequalities, in addition to celebrating cultural difference. Unlike classical fairy tales, Shrek is the story of an ugly ogre, who falls in love with a princess who is also an ogre like him. This reveals the fact that each person, whether a beauty or a "beast", a prince or an ogre, has his/her match and will be loved for whoever he/she is, regardless of his/her beauty or culture and even the society he/she belongs to.

Thus, it can be noted that Shrek, a fairy tale presented in film genre, has grown out of American culture rather than following the traditional understanding of the fairy tale hero and heroine. Considering the fact that "Americans are extremely independent, individualistic, and like to be different from each other" (101 Characteristics of Americans/American Culture) and since the American culture is different from the European one having its unique and new ways of living and lifestyle, being characterized by independence, Shrek can be considered more an Americanized/ modernized fairy tale rather than a classical one. 
As for the looks of the heroine in Shrek, it is not only untraditional but is extremely modern and weird. For example, while fighting during a battle it's the heroine who saves the hero instead of the traditional cliché of the hero saving the heroine.

Although Lori Baker-Sperry and Liz Grauerholz believe "that feminine beauty is a dominant theme and that tales with heavy emphases on feminine beauty are much more likely to have survived" (Baker-Sperry and Grauerholz 2003:711), Shrek controverses this understanding by having an ogre as a heroine, yet it has been such a success at the box offices of the cinemas that Shrek 2001 is succeeded by Shrek 2 in 2004, Shrek the Third in 2007, and Shrek Ever After in 2010.

According to Jane Caputi, the film Shrek is based upon a children's picture book by the New Yorker cartoonist William Steig (1990), who began writing and illustrating children's books at the age of 60. In Shrek 2001, Shrek is the main protagonist of the film voiced by Mike Myres and instead of the charming prince he is animated as a big and terrifying swamp dwelling green ogre. Although the word Shrek means monster in Yiddish (a German dialect used by the Jews in Germany before the Holocaust) and is related to concepts of terror and fear, yet Shrek has become such a "beloved popular phenomenon because the film's narrative clearly recognizes and reveres those loveable and enjoyable aspects of ourselves that our culture rejects by deeming them ugly and fearsome" (Caputi 2007:32). The film opens as Shrek ruminates in his outhouse, reading a fairy tale that says:

"Once upon a time, there was a lovely princess. But she had an enchantment upon her of a fearful sort which could only be broken by love's first kiss. She was locked away in a castle guarded by a terrible fire-breathing dragon. Many brave knights had attempted to free her from this dreadful prison, but none prevailed. She waited in the dragon's keep, in the highest room of the tallest tower, for her true love, and true love's first kiss".

(Shrek 2001) 
After this classical fairy tale beginning, we see something contrary to the cliché; we see Shrek enjoying a mud bath, and savoring a meal and a martini in his exceptionally cozy cottage in the base of a tree. He is isolated in his swampland home, which is a wetland and which Caputi describes as: "Wetlands so frequently are drained, filled-in and paved-over to allow human commerce and habitation. But in so doing, humans destroy one of nature's most precious places. . swamps are necessary, providing habitat for the most beauteous birds and creatures as well as spawning and fishing grounds Shrek's swamp is vividly contrasted with the egotistical Lord Farquaad's supposedly perfect but actually sterile city, from which he bans all the fairy tale beings"(Caputi 2007:33).

Shrek is isolated in his swampland home which will be taken away from him to be given to all the fairy tale characters that Lord Farquad put away from his "perfect city." The characters who come to stay at Shrek's swamp are; Pinocchio, Big Bad Wolf, Gephetto, Humpty Dumpty, Old Lady in the Shoe, The Three Bears, Muffin Man, Little Red Riding Hood, Mongo the Giant, Dwarves, Cyclops, Captain Hook, Black Knight, Three Little Pigs, Three Blind Mice, Gingerbread Man, Magic Mirror, and many others. All these characters are in fact traditional fairy tale characters that have appeared in many tales throughout history. Meanwhile, when these folk tale characters come to stay with him, Shrek makes a deal with Lord Farquaad, owner of Du Lack, which "is a perfect place" to save his princess. Traditionally, in Folk tales, the handsome prince is extraordinarily powerful, and he is the one who fights dragons to save his princess, however, in Shrek, Princess Fiona who is supposed to be saved by Lord Farquad, who will marry her, is saved by "the other" who is an ogre. Moreover, prince of Du Lack is ironically shorter than the princess, and is carried on shoulders of his soldiers to be seated on his horse.

In his swamp, Shrek is lonely and has no relationships with others. Later he comes to have a talking donkey as a guest in his house who turns to become his best friend; the donkey, who is the secondary protagonist, has a Scottish accent and is voiced by the famous comedian Eddie Murphy. Along 
with this weird scene; to get back his swamp, Shrek goes on a quest to save princess Fiona who is guarded by a dragon. However, to add weirdness to the classical in the process of making it modern, this dragon happens not to be a male character but a female one who falls in love with the witty, comical, talkative, and persistent donkey.

Moreover, the presence of this Dragon gives the film a happy ending instead of a sad one. According to Caputi, "In the standard patriarchal myths, the hero kills the dragon and is then able to "rescue", that is capture, the woman and make her his servant/wife. The narrative of Shrek, of course, gloriously reverses this hoary trope. This time, the dragon is female, but she is not slain to save the day. Rather, it is a Dragon who ultimately intervenes to bring about the happy ending"(Caputi 2007:36).

Thus, revealing this much controversy in the plot and character of the story that is related to the classical concept of fairy tales, it can be said that Shrek doesn't follow the footsteps of the traditional folktales. The classical concept of the fierce and evil character of the dragon is changed in Shrek since she is a female character who is so sensitive and so in love with the donkey (who never speaks like a donkey but makes gestures). She is charged with guarding Princess Fiona (voiced by Cameron Diaz) in her castle but she is not given a name, she has leathery bat wings, long ears, and a long, spadetipped tail to aid in balance. Moreover, this dragon has a much better characteristic than killing and conquering, on the contrary, she is the one who saves Shrek and Fiona from Lord Farquad on the day of her marriage. Thus, she is a modernized devil who doesn't look like the classical one in the collection of Grimm Brothers' tales.

Contrary to classical fairy tales, the princess in Shrek has a dual-natured character. By daytime she is human and "beautiful" whereas by night she turns to an "ugly" ogre. As she says in the film "by night one way, by day another." Consequently, Fiona has two sides, one of an ogre and another of a princess. She is both; a beast and a beauty. Fighting the dragon for Fiona's sake ironically with the help of his best friend - the donkey, Shrek saves the 
princess and they fall in love, and later they get married on the day of her supposed marriage to Lord Farquad.

\section{Conclusion}

Thus, comparing Shrek to classical folk tales in history that have magnificently beautiful princesses and extremely charming princes as characters, who live in palaces where the unbelievable becomes believable, and the unachievable - achievable; it can be deduced that Shrek, has a completely different type of plot, setting, and characters that subverts the fairy tale genre of the traditional fairy tale cliché since it is the story of an ogre who falls in love with another ogre, fights the dragon to save someone else's princess, and lives in an extremely muddy swamp where the dragon falls in love with his best friend who is a talking donkey.

For all the reasons mentioned above, the tale of Shrek the protagonist has a different plot, a different setting, and even a different type of characters than the classical fairy tales in history whether told by Brothers Grimm or by anyone else.

\section{References:}

1. Auden, W.H. (2015) Quotes about Fairy Tales. Goodreads. Goodreads Inc. Available at: JSTOR database [Accessed May 2018].

2. Bottigheimer, B.R. (Autumn, 1982) Tale Spinners: Submerged Voices in Grimms' Fairy Tales. 27, p.141-150. Available at: JSTOR database [Accessed May 2018].

3. Bottigheimer, B.R. (Oct. 1989) Fairy Tales, Folk Narrative Research and History. 3, pp. 343-357. Available at: JSTOR database [Accessed May 2018].

4. Caputi, J. (Autumn, 2007) Green Consciousness: Earth-Based Myth and Meaning in Shrek. Ethics and the Environment, 12, 2: 23-44. Available at: JSTOR database [Accessed May 2018].

5. Hurley, L.D. (Summer, 2005) The Journal of Negro Education. Seeing White: Children of Color and the Disney Fairy Tale Princess. 74, 3:221-232. Available at: JSTOR database [Accessed May 2018]. 
6. Baker-Sperry, L. and Grauerholz, L. (Oct., 2003) The Pervasiveness and Persistence of the Feminine Beauty Ideal in Children's Fairy Tales. Gender and Society, 17, 5: 711-726. Available at: JSTOR database [Accessed May 2018].

7. Wardetzky, K. (Apr. - Jun., 1990) The Structure and Interpretation of Fairy Tales Composed by Children, Journal of American Folklore, 103, 408, 157176. Available at: JSTOR database [Accessed April 2018].

8. Zipes, J. (2000) The Oxford Companion to Fairy Tales. Oxford: OUP.

9. 101 Characteristics of Americans/American Culture. Available at: <http://www.press.umich.edu/pdf/9780472033041-101AmerCult.pdf> [Accessed April 2018].

\section{Sources of Data:}

Shrek Rating: PG (for mild language and some crude humor)

Genre: Animation, Comedy, Kids \& Family

Directed By: $\quad$ Vicky Jenson, Andrew Adamson

Written By: Joe Stillman, Roger S.H. Schulman, Terry Rossio, Ted Elliott, Conrad Vernon, Cody Cameron

In Theaters: $\quad$ May 18, 2001 Wide

On Disc/Streaming: Nov 2, 2001

Box Office: \$266,982,666

Runtime: $\quad 93$ minutes

Studio: $\quad$ Dreamworks

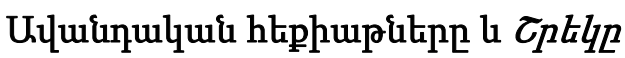

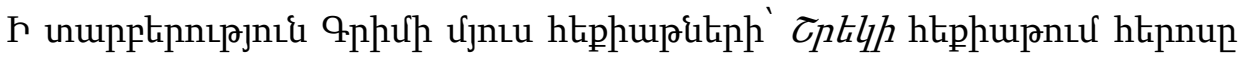

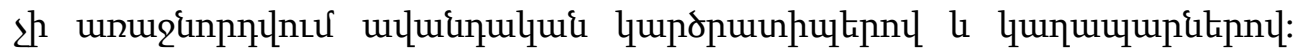

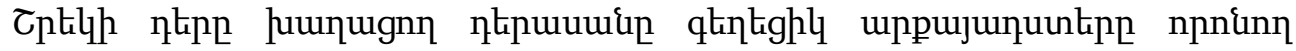

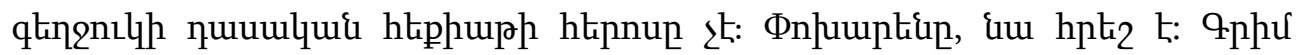

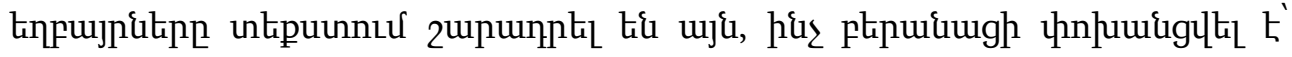




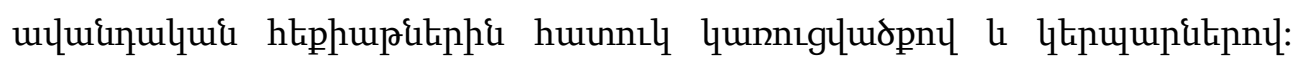

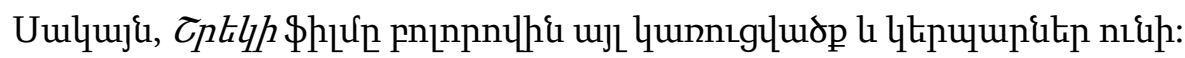

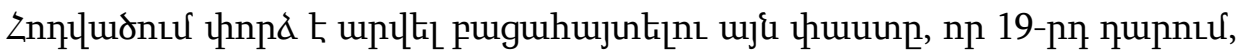

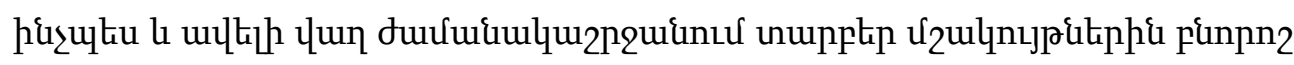

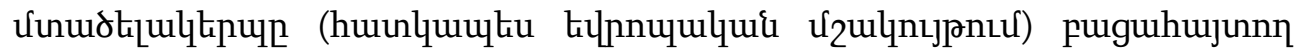

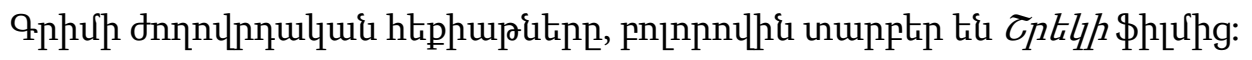

